\title{
Evaluation of medicines advertising in medical journals
}

\author{
Daliana Maria Berenice de Oliveira Souza, Suellen Cristiane Medeiros de Lima, Almária Mariz \\ Batista, Maria Cleide Ribeiro Dantas de Carvalho*
}

\author{
Laboratory of Advertising Monitoring for Products Subject to Health Surveillance, Department of Pharmacy, Health Sciences \\ Center, Federal University of Rio Grande do Norte
}

\begin{abstract}
This work intended to analyze the advertising of medicines requiring medical prescription, divulged into three journals of the neurology and cardiology areas addressed to healthcare professionals. The analysis was based on current legislation, among other criteria, as well as specific literature. The presence of the following items was investigated: registration number, drug name, specific indications, contraindications; cautions and warnings; adverse reactions; possible side effects; posology; legibility of technical-scientific information and bibliographic references, phrases and/or expressions about the medication benefits, as compared to other drugs; safety warnings, healing promises and pictures of people smiling, and the quotations confirmation based on bibliographic references. Among the evaluated legal criteria, it was observed the absence of legibility in technical-scientific information in $85 \%$ of advertisements; absence of side effects in $23 \%$; absence of cautions and warnings in $15 \%$; of contraindications in $12.8 \%$; of posology in 6.4\%; of registration numbers in $2.7 \%$ and of the Common Brazilian Denomination/Common International Denomination (Denominação Comum Brasileira/Denominação Comum Internacional - DCB/DCI) in $0.6 \%$. Out of 130 statements respecting advantages face to others drugs, $23.8 \%$ were not confirmed and out of 48 divulged safety messages, $41.7 \%$ could not be found in quoted references. The pictures of people smiling was a resource used in $42.2 \%$ of advertisements. Out of 1362 references analyzed, $19.7 \%$ were not found and $37.1 \%$ of quoted affirmations weren't confirmed.
\end{abstract}

Uniterms: Medicines/advertising. Medicines/prescription. Medicines/legislation.

Este trabalho objetivou analisar propagandas de medicamentos sujeitos à prescrição, que foram veiculadas em três periódicos das áreas de cardiologia e neurologia, dirigidos a profissionais de saúde. A análise envolveu critérios baseados na legislação em vigor, além de outros, e das referências bibliográficas. Averiguou-se a presença dos seguintes itens: número de registro, nome do fármaco, indicações terapêuticas, contra-indicações, cuidados e advertências, reações adversas, efeitos colaterais, posologia, legibilidade das informações técnico-científicas e referências bibliográficas, frases e/ou expressões sobre vantagens ante outros fármacos, mensagens de segurança, promessas de cura e imagens de pessoas sorridentes, além da confirmação das citações com base nas referências bibliográficas. Dentre os critérios legais avaliados, observou-se a ausência de legibilidade das informações técnico-científicas em $85 \%$ das peças promocionais; a ausência dos efeitos colaterais em $23 \%$; a ausência de cuidados e advertências em 15\%; de contra-indicações em 12,8\%; de posologia em $6,4 \%$; do número de registro em $2,7 \%$ e da Denominação Comum Brasileira/Denominação Comum Internacional (DCB/DCI) em 0,6\%. Das 130 afirmações relativas a benefícios frente a outros fármacos, $23,8 \%$ não foram confirmadas; e das 48 mensagens de segurança veiculadas, $41,7 \%$ não tinham respaldo nas referências citadas. As imagens de pessoas sorridentes foram recurso usado em $49,2 \%$ das peças promocionais. Das 1.362 referências analisadas, $19,7 \%$ não foram encontradas e $37,1 \%$ das afirmações referenciadas não foram confirmadas.

Unitermos: Medicamentos/publicidade. Medicamentos/prescrição. Medicamentos/legislação.

\section{INTRODUCTION}

The commercial promotion of medicines refers to

*Correspondence: M. C. R. D. Carvalho. Laboratório de Monitoração de Propaganda de Produtos Sujeitos à Vigilância Sanitária. Departamento de Farmácia, Universidade Federal do Rio Grande do Norte - UFRGN. Av. General Gustavo Cordeiro de Farias, s/n, 59010-180 - Natal - RN, Brasil. E-mail: cleidecarvalho@hotmail.com "all informative and persuasive activities developed by medicines producers, in order to induce their prescription, provision, acquisition or utilization" (SOBRAVIME, 2001).

According to Jesus (2006), the same pharmaceutical industry which invests millions in research looking for the healing of people, invests also very high amounts 
all over the world in mass media. So that in United States in 2004, the American pharmaceutical companies have spent about US $\$ 57.5$ billion in promotional activities while, in the same year, such companies spent only US\$31.5 billion in Research \& Development, including also funds from the American government; demonstrating so that these companies have spent almost the double of their investments in Research \& Development of new medicines, with advertising of their products (Gagnon, Lexchin, 2008).

In Brazil, according some studies, the pharmaceutical industry spends about $25 \%$ of their global invoicing in advertising and correlate activities (Barros, Joany, 2002). Other studies make reference to spends varying from 20 to $40 \%$ of the invoicing, representing the double or triple of the amount destined to investigation and development of new drugs (Barros, 2004; Câmara dos Deputados, 2000).

According to Temporão (1986), the pharmaceutical propaganda effectively achieves a change in the physicians' standard of prescription, besides to be considered, for many times, as their main source of therapeutic updating. Therefore, the pharmaceutical industry utilizes diverse techniques, such as the support of multiple medical congresses; the regular visitation to physicians by the pharmaceutical representatives (the "reps"), with ample distribution of free samples, gifts and printed material; beyond continuous advertising in specialized magazines and journals (Barros, 1995; Hodges, 1995; Lexchin, 1993; Temporão, 1986; Zipkin, Steinman, 2005).

As an attempt to change the standard of medicines consumption, the pharmaceutical companies make use of different forms of advertising addressed as to outsider public, as to healthcare professionals. Thereby, their commercial messages achieve an extensive range of professionals and people within the healthcare area, from physicians and pharmacists up to drugstore owners and patients, attaining so to decisively influence the medicines prescription, sale and consumption. (Pizzol, Silva, Schenkel, 1998).

There are studies evidencing the existence of a direct relationship between the more advertised medicines in medical journals and magazines, and the frequency of their prescription by physicians (Barros, 2000; Krupa, Vener, 1985).

According to Pizzol, Silva and Schenkel (1998), considering the possible impact of advertising on therapeutic practices, it should be expected that medicines advertising had always good quality, providing important and reliable information about the advertised product. In addition, another study has concluded that $50 \%$ of advertisements in medical journals do not present the warnings and precautions respecting the use of respective products, and $40 \%$ of them do not include neither contraindications, nor adverse reactions (Barros, Joany, 2002), being so in complete disagreement with the ethical criteria for medicines advertising that was proposed by WHO (World Health Organization), to assure consumers' safety and rights (WHO, 1988).

The importance of medicines advertising as incentive for their consumption is proven by the enormous amounts destined by pharmaceutical industry for this purpose (Pizzol, Silva, Schenkel, 1998). Fagundes et al. (2007), in a research developed with physicians, in order to examine the way they perceive the effects of advertising on their professional activity, verified that $68 \%$ of them believe in the direct influence of advertising on their prescription habits; in addition, $14 \%$ of them affirmed to prescribe specific medicines as a function of rewards reception from the respective pharmaceutical companies. Other studies evaluating the physicians' behavior face to pharmaceutical industry promotions and advertising, have proven the influence of these persuasion strategies on the physicians' prescription habits (Castresana, Mejia, Aznar, 2005).

Any form of medicines divulgence, due to inherent characteristics of these products resulting from a direct relationship between health and disease, should be supported by ethical and legal groundings, presenting not only the benefits and qualities of the advertised product, but also its risks, precautions of use and contraindications, contributing so for the rational use of medicines and an improvement in population health. However, there is an evident conflict of interests and objectives between the medicines producers and distributors, whose target is to increase their own profits, and the medicines advertising regulatory organs, whose main objective consists in support and promote the health assistance improvement, by means of the rational use of medicines (Resener, 2004).

Studies developed in Russia about medical magazines advertising, pointed out that in only $40 \%$ of advertisements, the generic name of medicines appeared; in $45 \%$, some indication was mentioned; in $11 \%$, warnings and contraindications were mentioned; in 5\%, the pharmacological interactions were presented; and only in $2 \%$, the references were presented. The study discusses the little access of physicians to safe information sources, and concludes that pharmaceutical advertising does not provide the basic information for a competent prescription, pointing out the necessity of governmental regulation, once the Ethical Criteria for Promotion of Medicines, published by WHO, are not followed voluntarily (Vlassov et al., 2001). 
Mejia and Avalos (2001), analyzing medicine advertising pieces addressed to physicians, observed that adverse reactions, warnings and contraindications were absent of such promotional material in all evaluated advertisements. Besides, out of a total of 131 quoted references, $60(46 \%)$ were incorrectly listed and, because of that, it was not possible to have access to them. Out of the 71 correctly listed pieces, 49 (69\%) were not found into four large medical bookstores of Buenos Aires. The 22 found references were revised and in 12 of them, the objective of these researches coincided with the established in the advertisements.

Many professionals rely on the sponsorship from pharmaceutical industry, in the same way as medical magazines rely in experiments sponsored by pharmaceutical companies, despite the consequent conflict of interests and evidences that sponsored articles are, many times, more promotional than other articles (Bero, Galbraith, Rennie, 1992; Smith, 2003).

The specialized magazines are, almost always, edited by the pharmaceutical companies themselves, being that in some cases, such companies have their own department of communication (house agency), assuring total safety to company (Jesus, 2000).

The companies responsible for the elaboration of advertising campaigns use as one of their most common arguments, the necessity for a given medicine, that is, they generate a necessity, create a problem and present the medicine as a rapid, safe, effective and riskless solution. In a market were many therapeutic options exist for a given purpose, the advertising becomes a differential element to better sell a product (Kessler et al., 1994).

It is obvious that the divulgence of tendentious advertising campaigns, whose objectives are of strictly commercial nature, stimulates the growing irrational use of medicines. So, it is evident the necessity of reevaluation of current legislation, mainly the one about the advertising of medicines sold exclusively under prescription, which should be addressed exclusively to physicians, and, nevertheless, continues to be addressed by companies to outsider public, by means of diverse medias, in a way to become them more effective and with lower probability of subjective interpretations (Fagundes et al., 2007).

\section{METHODS}

This study has analyzed the advertisements of medicines subject to medical prescription, divulged by 3 publications addressed to medical class, in the areas of neurology and cardiology.

The Magazine A is a quarterly journal, indexed in the EXCERPTA MEDICA, INDEX MEDICUS LATINOAMERICANO, LILACS and PSYCINFO databases, and classified as Qualis B National for the Medicine Areas I and II; the Magazine B is a monthly journal, indexed in the Cumulated Index Medicus (NLM - Bethesda) - MEDLINE; EMBASE; LILACS and SCIELO databases and classified as Qualis $C$ International for the Medicine Areas I and II and the Magazine $\mathbf{C}$ is a quarterly journal, indexed in the BIREME-LILACS and classified databases as Qualis B National for the Medicine Areas I and II.

The analyzed advertisements were obtained from volumes corresponding to the years of 2005 to 2007 of Magazines A, B and C.

The advertisements analysis followed to general criteria, as follows: 1) a legal criterion, that is, if they were in accordance to current legislation and 2) a scientific criterion, which has analyzed the reference quotations appearing in the advertisements.

The evaluation of legal criterion was based on Decree n. 79094/1977 (Brasil, 1977) and Resolution RDC n. $102 / 2000$ (Brasil, 2000), where the following items have been observed: 1) registration number; 2) active principle according to DCB or DCI; 3) therapeutic indications; 4) contraindications; 5) cautions/precautions and warnings; 6) adverse reactions; 7) side effects; 8) posology; and 9) legibility of technical-scientific information (indications, contraindications, cautions and warnings, adverse reactions, side effects and posology) and bibliographical references.

Besides to legal criteria, it was also evaluated if the advertisements brought phrases and/or expressions about: 1) advantages face to other drugs; 2) safety messages; 3 ) healing promises; besides 4) images of smiling people.

The analysis of bibliographical references has verified the following items: 1) type of referenced scientific material (books, journal articles and package inserts); 2) if the refereed materials were localized; 3 ) if the references were listed according to International Committee of Medical Journal Editors (ICMJE) and 4) if the information contained in advertisements was faithful to quoted reference.

For the reading of technical-scientific information (indications, contraindications, cautions and warnings, adverse reactions, side effects and complete posology) and bibliographic references, it was utilized a manual magnifier with increase of 6 times.

\section{RESULTS AND DISCUSSION}

Out of the 2034 pages compounding the analyzed publications, 187 (9.2\%) were occupied by advertisements. Almost the totality of advertisements (99.9\%) 
occupied a complete page of the respective magazine, and 6 medicines presented small versions of their 'package insert' inserted within the respective publication body.

The analyzed issues of Magazine A were composed by 212 pages, being that $30(14.2 \%)$ of these pages contained advertisements and a single small version of package insert within the publication body. In every issue of this magazine, an average of 7.5 advertisements was found.

The analyzed issues of Magazine B were composed by 1,493 pages, being that $144(9.6 \%)$ of these pages contained advertisements and 5 small versions of package insert within the publication body. In every issue of this magazine, an average of 12 advertisements was found.

The analyzed issues of Magazine $\mathbf{C}$ were composed by 329 pages, with advertisements only in the overleaf of superior cover and in the obverse and overleaf of the inferior cover, totalizing $12(3.9 \%)$ pages. In every issue of this magazine, an average of 3.3 advertisements was found.

It was verified that, besides the significant number of pages destined to advertisement, the magazines A and $B$ presented advertisements from different pharmaceutical companies, while in the magazine $\mathrm{C}$, all advertisements were from a single pharmaceutical company. Should medical journals divulge pharmaceutical advertising? According to Smith (2007), yes they do; because the pharmaceutical advertising represents an excellent source of funds, contributing so for the magazines financial independence. However, it is necessary to be careful to avoid a pharmaceutical company acquiring the status of exclusive advertiser, in order to preserve the editorial independence of these magazines.

\section{Legal Analysis}

The data of legal analysis are demonstrated at Table
I. The analyzed items were based on article $3^{\text {rd }}$, item I of General Requisites, at article $13^{\text {th }}$, item I, clauses "a" to ' $\mathrm{f}$ " of Requisites for Medicines Sold under Prescription, established at RDC n. 102/2000 and at article $94^{\text {th }}$ of Decree n. 79094/1977 (Brasil, 2000; 1977).

Table II presents the evaluation of legal criteria per journal. It was noticed that, despite the differences of indexation of these journals, the quality of divulged advertisements is similar.

The trade name has appeared in all advertisements, always detached. The DCB has also appeared in all advertisements, always in background, with font size lower than that of trade name, but legible. The emphasis given to trade name to reveals the intention to fix in prescriber memory the medicine trademark. According to Kotler (2000), the advertising is classified into three types: the

TABLE I - Evaluation of Legal Criteria

\section{EVALUATED ITEMS}

PRESENCE IN THE ADVERTISEMENTS

\begin{tabular}{llcc}
\cline { 3 - 4 } & & $\mathbf{N}$ & $\mathbf{\%}$ \\
\hline 1 & Trade name & 187 & 100 \\
2 & Registration number & 182 & 97.3 \\
3 & Active principle according to & 187 & 100 \\
& DCB or DCI & & \\
4 & Indications & 187 & 100 \\
5 & Contraindications & 163 & 87.2 \\
6 & Caution/Warning & 159 & 85 \\
7 & Adverse reactions & 160 & 85.6 \\
8 & Side effects & 144 & 77 \\
9 & Posology & 175 & 93.6 \\
10 & Legibility of information & 28 & 15 \\
\hline
\end{tabular}

TABLE II - Evaluation of legal criteria per journal

\begin{tabular}{llcccccc}
\hline \multirow{2}{*}{ LEGAL CRITERIA } & \multicolumn{5}{c}{ PRESENCE OF LEGAL CRITERIA } \\
\cline { 3 - 7 } & & \multicolumn{2}{c}{ JOURNALA } & \multicolumn{2}{c}{ JOURNAL B } & \multicolumn{3}{c}{ JOURNAL C } \\
\cline { 3 - 7 } & & $\mathrm{N}^{\circ}$ & $\%$ & $\mathrm{~N}^{\circ}$ & $\%$ & $\mathrm{~N} /$ & $\%$ \\
\hline 1 & Trade name & 30 & 100 & 144 & 100 & 13 & 100 \\
2 & Registration number & 27 & 90 & 142 & 98.6 & 13 & 100 \\
3 & DCB & 30 & 100 & 144 & 100 & 13 & 100 \\
4 & Indications & 30 & 100 & 144 & 100 & 13 & 100 \\
5 & Contraindications & 29 & 96.6 & 121 & 84 & 13 & 100 \\
6 & Caution and Warning & 27 & 90 & 119 & 82.6 & 13 & 100 \\
7 & Adverse reactions & 29 & 96.6 & 118 & 81.9 & 13 & 100 \\
8 & Side effects & 26 & 86.6 & 118 & 118.9 & 0 & 0 \\
9 & Posology & 30 & 100 & 132 & 91.6 & 13 & 100 \\
10 & Legibility & 3 & 10 & 25 & 17.4 & 0 & 0 \\
\hline
\end{tabular}


persuasive, the reminder and the informative types; and for him, these three forms should be utilized according the life cycle stage in which the product is found in the market. The emphasis given to trade name is related to remember advertising, which is focused in remember the product buyers and aims to maintain visible to consumers the trademark.

The main infraction (85.6\%) appearing in the advertisements was the presentation of technical-scientific information (indications, contraindications, cautions and warnings, adverse reactions, side effects and complete posology) written in very small fonts, which practically precluded their visual reading. In some cases, besides the font size, the font color in contrast with paper background color complicated too much the comprehension of information.

According to article $94^{\text {th }}$ of Decree n. 79094/1977, "The labeling, package inserts, labels, flysheets or any printed modality referring to products treated in this Regulation, will have the dimensions necessary to easy visual reading, observing the minimum height limit of one millimeter and being written in a way to facilitate the consumer comprehension" (Brasil, 1977).

Besides, the RDC n. 102/2000, Title I - General Requisites, in the article $3^{\text {rd }}$, item I determines that:

In advertising, promotional messages and/or other practices whose objective is the promotion of medicines, the general requisites should be accomplished, without prejudice of those particularly established for determined types of medicine, being requested:

I - to appear, in Portuguese, in clear and precise form, the main contraindication, if any, such as registered at National Agency of Health Surveillance (Brasil, 2000).

The analyzed advertisements, therefore, accomplish only partially the current norms regulating medicines advertising, as they present the required information but hamper its access, when presenting it in a non clear way, embarrassing the visual reading. The advertisements lose, in such a way, the objective to become an informative tool for physicians, emphasizing only the elements really wished to be memorized, such as the medicine trade name and some pharmacological actions interesting for therapeutics, leaving unperceived, mainly the restrictive and negative information presented by the medicine (contraindications, cautions and warnings, adverse reactions, side effects), which are indispensable for its rational use. In addition, the suppression of so important information becomes these advertisements deceptive by omission, once the manufacturer lays aside the information of essential product data, which could lead the consumer (in this case, the prescriber) to commit mistakes.

The Code of Consumer Defense (Código de Defesa do Consumidor-CDC) determines as basic consumer rights (item III of article $6^{\text {th }}$ ) "The adequate and clear information respecting different products and services, with correct quality specification, characteristics, composition, quality and price, as well as respecting the presented risks". Besides, the article $8^{\text {th }}$ determines that "The products and services put in the consumption market will not result in risks to consumer health or safety, except for those considered normal and foreseeable, resulting from the product nature and possession; being obliged the product suppliers, under any hypothesis, to give the necessary and adequate information respecting it". Respecting to advertising, the CDC establishes that it is prohibited all deceptive or abusive advertising (article 37) and defines this type of advertising as those that renounced to inform about product or service essential data $\left(\S 3^{\text {rd }}\right.$ of article $37^{\text {th }}$ ) (Brasil, 1990). It is observed that, despite to have his rights assured by Law, the consumer is having his rights systematically injured, by deceptive and abusive advertising.

In the same way, Mejia and Avalos (2001), analyzing medicine advertisements addressed to physicians, observed that adverse reactions, warnings and contraindications were absent in all evaluated advertisements.

As for many physicians, the advertising is the single source of information respecting medicines (Barros, 1995), it is observed that this knowledge is effectively damaged by the manner of presentation of these reports.

\section{Analysis of other criteria}

Table III shows the evaluation of other criteria, besides the legal ones. None analyzed advertisement presented phrases and/or expressions denoting healing promise. In $69.5 \%$ of analyzed advertisement, there was some type of expression demonstrating advantage respecting to other drug, in $25.7 \%$ of advertisements there was messages about the medicine safety. The indications of advantage over other drugs and the safety messages were always accompanied by quotations of articles presenting comparative studies. Out of 130 affirmations respecting to advantages face other drugs contained in the advertisements, $23.8 \%$ were not confirmed. Respecting to 48 divulged safety messages, $41.7 \%$ were not supported by references, therefore, they were not ratified. 
TABLE III - Evaluation of other criteria per journal

\begin{tabular}{llcccccc}
\hline \multirow{2}{*}{ OTHER CRITERIA } & \multicolumn{5}{c}{ PRESENCE OF OTHER CRITERIA } \\
\cline { 3 - 7 } & & \multicolumn{2}{c}{ JOURNAL A } & \multicolumn{2}{c}{ JOURNAL B } & \multicolumn{2}{c}{ JOURNAL C } \\
\cline { 2 - 7 } & & $\mathrm{N}^{\circ}$ & $\%$ & $\mathrm{~N}^{\circ}$ & $\%$ & $\mathrm{~N} /$ & $\%$ \\
\hline 1 & Advantages face to other drugs & 27 & 90 & 102 & 70.8 & 1 & 7.7 \\
2 & Safety messages & 12 & 40 & 30 & 20.8 & 6 & 46.2 \\
3 & Healing promise & 0 & 0 & 0 & 0 & 0 & 0 \\
4 & Images of smiling people & 0 & 0 & 88 & 61.1 & 4 & 30.8 \\
\hline
\end{tabular}

The images of people smiling and demonstrating health represent a resource used in $49.2 \%$ of advertisements. According to Silva, Barreto and Facin (2006), the images shown through advertising, in the majority of cases, are produced with specific intentions and, for many times, are mere illusions of reality, once they do not represent the more frequent physical, psychological, social and economical characteristics of people to which they are addressed, but on the contrary, they valorize characteristics that are typical of a minority, which difficultly could be attained by a common middle citizen. Exactly because the low incidence of such characteristics, the difficulty to attain them and their exhaustive suggestion in the media, they become the aimed ideal of "perfection". Respecting this, Aumont (1993) affirms that images have as their first purpose, to assure, reinforce, reaffirm and explicit our relationship with the visual world: they perform a role of visual discovery and this relationship is essential for our intellectual activity. The spectator builds the image and the image builds the spectator. This approach consists, before everything, in treating the spectator as an active partner of the image, emotionally and cognitively; and also as a psychic organism on which the image, by its turn, also acts.

\section{Analysis of references}

The bibliographical materials referenced in the advertisements were constituted by: journal articles $(87.5 \%)$, package inserts $(7.9 \%)$, product monographs $(1.3 \%)$, books $(1.2 \%)$, filed data $(0.9 \%)$, and others unidentified
$(1.1 \%)$ due to incomplete references.

Out of 1362 references quoted in the advertisements, 268 (19.7\%) were not localized; such material was constituted by $223(83.2 \%)$ journal articles, $18(6.7 \%)$ product monographs, 12 (4.5\%) filed data and $15(5.6 \%)$ unidentified materials.

The unidentified materials presented minimum data, did not allowing even their classification respecting the type of bibliographic material. Generally, the non localized references omitted some important datum, essential for their localization, and were not according to norms of International Committee of Medical Journal Editors (ICMJE, 2008). Data omission precluding the access to information appearing in advertising pieces, puts in check their own credibility. In the same way, Spielmans et al. (2008), evaluating the accuracy of advertising divulged in medical journals, verified that more than a half $(50.2 \%)$ of affirmations done in these advertisements, did not provide an accessible source that could be used to check their veracity.

The bibliographical material found $(80.3 \%)$ was evaluated to verify if it was in accordance with the quotation done in the respective advertisement. In $62.9 \%$ of cases, the quotations were confirmed.

Table IV demonstrates the evaluation of quotations per type of journal.

It was verified that $37.1 \%$ of affirmations appearing in the analyzed advertisements were not confirmed by their referenced sources; a fact that compromises too much the quality of divulged information. Villanueva et al. (2003),

TABLE IV - Evaluation of quotations per type of journal

\begin{tabular}{lcccccc}
\hline & \multicolumn{2}{c}{ CONFIRMED } & \multicolumn{2}{c}{ NOT CONFIRMED } & \multicolumn{2}{c}{ TOTAL } \\
\cline { 2 - 7 } & $\mathrm{N}^{\circ}$ & $\%$ & $\mathrm{~N}^{\circ}$ & $\%$ & $\mathrm{~N}^{\circ}$ & $\%$ \\
\hline JOURNAL A & 130 & 69.1 & 58 & 30.9 & 188 & 100 \\
JOURNAL B & 497 & 59.2 & 343 & 40.8 & 840 & 100 \\
JOURNAL C & 61 & 92.4 & 5 & 7.6 & 66 & 100 \\
\hline TOTAL & $\mathbf{6 8 8}$ & $\mathbf{6 2 . 9}$ & $\mathbf{4 0 6}$ & $\mathbf{3 7 . 1}$ & $\mathbf{1 0 9 4}$ & $\mathbf{1 0 0}$ \\
\hline
\end{tabular}


analyzing advertisements published in six Spanish medical journals in 1997 , observed that $41.1 \%$ of promotional affirmations were not supported by references. In the same way, Lankinen et al. (2004), evaluating medicine advertisements divulged in four medical journals, verified that $21 \%$ of quoted references were not relevant for the respective affirmations, concluding that referenced affirmations contained in pharmaceutical advertisements could present a more scientific image, however, such references do not assure the quality of their respective affirmations.

These results demonstrate that many pharmaceutical advertisements violate the RDC n. 102 in its article $15^{\text {th }}$, which specifies that "The quotations, tables and other illustration extracted from scientific publications and utilized in any advertisement, publicity or promotion, should be faithfully reproduced and specify the complete bibliographical reference" (Brasil, 2000). These groundless advertisements violate also the Code of Consumer Defense, which establishes at its $\S 1^{\text {st }}$ of article $37^{\text {th }}$ that "It is deceptive any modality of information or communication of promotional character entirely or partially fake, or that is, by any other mode, even by omission, able to induce the consumer in a mistake [...]" (Brasil, 1990). Taking it into account, the referenced and unconfirmed affirmations constitute deceptive advertising, being liable, therefore, for applicable legal sanctions.

Usually, physicians do not admit their respective prescription habit is subjected, in higher or lower grade, to influence from promotional activities promoted by pharmaceutical industry, in which substantial resources are invested. Particularly addressed to physicians, such expenses are, ultimately, defrayed by the consumer, as they are inlaid in the products price. So significant expenditures (on the order of 20 to $25 \%$ of global invoicing) applied in advertising could only be explained, by the expected return in terms of sales and profits. In the United States, just in the year of 2004, US\$ 57.5 billion were spent by pharmaceutical companies in promotional activities (Gagnon, Lexchin, 2008).

The advertising inserted into medical journals, responsible for their defrayal, was already object of interest of different foreign studies. One of them intended to demonstrate the existing relationship between an increase in the prescription rate of a given product, and the respective number of divulged advertisements. In this study, the authors observed that high investments in advertising are necessary to successfully achieve high sales levels, for a drug that has no precise effect in the improvement of some specific psychological conditions (Krupka, Vener, 1985). On the other hand, it was already verified that a less critical attitude from physicians, face to pharmaceutical companies promotional strategies, is associated to a low quality prescription (Haaijer-Ruskamp, Hemminki, 1993).

In Brazil, according to Barros (1995), the advertising addressed to physicians succeeds to change their prescription habits. Fagundes et al. (2007), developing a study with physicians in Brasilia (DF), verified that $68 \%$ of them believe in the direct influence of advertising on prescription and $14 \%$ said to prescribe medicines as a function of rewards reception. Trevisol, Ferreira and Karnopp (2007), in a study about medicines advertising developed with medicine teachers and students, verified that between those teachers, $53.6 \%$ considered to be never or rarely influenced by the pharmaceutical industry, and 53.7\% affirmed to believe that their professional colleagues are so. Between the students, $43.2 \%$ believe that in the future, as graduated physicians, they will not or rarely be influenced, however, $42.0 \%$ believe that physicians are always or frequently influenced. For $41.7 \%$ of them, the information from pharmaceutical industry representatives is good or optimal, in addition, $74.8 \%$ reported that pharmaceutical industry could contribute for their professional practice.

\section{CONCLUSIONS}

Among the legal criteria evaluated in advertisements, it was verified as the main irregularity, the lack of legibility in technical-scientific information in $85 \%$ of cases; in $23 \%$, the omission of side effects; in $15 \%$ the absence of cautions and warnings; in $12.8 \%$ the omission of contraindications; in $6.4 \%$ the absence of posology; in $2.7 \%$ the lack of registration number; and in $0.6 \%$ the absence of DCB/DCI. In addition, not always true arguments were divulged to proclaim product advantages; which characterizes a violation of current country legal norms, as well as ethical criteria established by WHO.

The marketing strategies utilized in persuasion involved, mainly, affirmations of advantage face other drugs and safety messages, which not always reflected the veracity of quoted bibliographical support. Besides, another much utilized tool was the divulgence of smiling people demonstrating health, in order to reinforce the established idea respecting the role of medicines in health recovery.

Out of the affirmations appearing in advertisements, $37.1 \%$ were not confirmed by referenced studies, which deposes against the quality of divulged information, as medicines are not merely a merchandising, but products that represent a potential danger if wrongly administered. Therefore, their advertisements should have a strictly informative character, obeying rigorously the legislation and ethics principles, once they could be used by many physicians as their single source of therapeutic updating. 
The non accomplishment of current legislation, the difficulty and/or impossibility of access to important information, and the excess of arguments that are not always true and/or present ambiguities sometimes, compromise the quality of divulged information giving margin to different interpretations, and could induce prescription mistakes and negatively influence the consumption of medicines, becoming irrational their utilization.

Face to these substantiations, in the same way as journals keep an editorial council to evaluate the articles to be published, they could also keep a team to analyze the advertisements to be divulged, correcting possible distortions and collaborating for the reliability of information presented in their successive editions.

\section{REFERENCES}

AUMONT, J. A imagem. Campinas: Papirus, 1993. 350 p.

BARROS, J. A. C. A (des)informação sobre medicamentos: o duplo padrão de conduta das empresas farmacêuticas. $C a d$. Saúde Pública, Rio de Janeiro, v.16, n.2, p.421-427. 2000.

BARROS, J.A. C. Políticas farmacêuticas: a serviço dos interesses da saúde? Brasília: UNESCO/ANVISA; 2004. 272 p.

BARROS, J. A. C. Propaganda de medicamentos: atentado à saúde? São Paulo: Hucitec/Sobravime. 1995. 207 p.

BARROS, J. A. C.; JOANY, S. Anúncios de medicamentos em revistas médicas: ajudando a promover a boa prescrição? Ciênc. Saúde Colet., v. 7, n. 4, p. 891-898. 2002.

BERO, L.; GALBRAITH, A.; RENNIE, D. The publication of sponsored symposiums in medical journals. N. Engl. J. Med., v. 327, n. 16, p. 1135-1140. 1992.

BRASIL. Código de Defesa do Consumidor. Lei n ${ }^{\circ}$. 8.078, de 11 de setembro de 1990. Dispõe sobre a proteção do consumidor e dá outras providências. Available at: $<$ http://www.procon.df.gov.br/005/00502001.asp?ttCD_ CHAVE $=4565 \#>$. Accessed on: 10 mar., 2008.

BRASIL. Decreto ${ }^{\circ}$ 79.094, de 5 de janeiro de 1977. Regulamenta a Lei $\mathrm{n}^{\circ}$ 6360, de 23 de setembro de 1976, que submete a sistema de vigilância sanitária os medicamentos, insumos, farmacêuticos, drogas, correlatos, cosméticos, produtos de higiene, saneantes e outros. Diário Oficial da União, Brasília, DF, 7 jan. 1977. Available at: <http://e-legis.bvs.br/leisref/ public/showAct.php?id=16611\&word=>. Accessed on: 10 mar. 2008 .
BRASIL. Resolução RDC nº. 102, de 30 de novembro de 2000. Aprova o regulamento sobre propagandas, mensagens publicitárias e promocionais e outras práticas cujo objeto seja a divulgação, promoção ou comercialização de medicamentos de produção nacional ou importados, quaisquer que sejam as formas e meios de sua veiculação, incluindo as transmitidas no decorrer da programação normal das emissoras de rádio e televisão. Diário Oficial da União, Brasília, DF, 1 Jan. 2000. Available at: <http://elegis.anvisa.gov.br/leisref/public/showAct.php?id=11079>. Accessed on: 9 mar. 2008.

CÂMARA DOS DEPUTADOS. Relatório da CPI dos medicamentos. Brasília: Centro de Documentações, Câmara dos Deputados, Coordenação de Publicações. Brasília, 2000. 279p.

CASTRESANA, L.; MEJIA, R.; AZNAR, M. The atitude of physicians regarding the promotion strategies of pharmaceutical industry. Medicina (B Aires), v.65, n.3, p.247-251. 2005.

FAGUNDES, M. J. D.; SOARES, M. G. A.; DINIZ, N. M.; PIRES, J. R.; GARRAFA, V. Análise bioética da propaganda e publicidade de medicamentos. Ciênc. Saúde Colet., v. 12, n. 1, p. 221-229. 2007.

GAGNON, M. A.; LEXCHIN, J. The cost of pushing pills: a new estimate of pharmaceutical promotion expenditures in the United States. PLoS Medicine, v.5, n.1, p.29-33. 2008. Available at: <www.plosmedicine.org 0029>. Accessed on: 3 feb. 2008 .

HAAIJER-RUSKAMP, F. M.; HEMMINKI, E. The social aspects of drug use. WHO Reg. Publ., Eur. Ser., v.45, número?, p.97-124. 1993.

HODGES, B. Interactions with the pharmaceutical industry: experiences and atitudes of psychiatry residents, interns and clerks. Can. Med. Assoc. J., v.153, n.5, p.553-559. 1995.

ICMJE. Uniform Requirements for Manuscripts Submitted to Biomedical Journals: Writing and Editing for Biomedical Publication. Available at: <http://www.icmje.org/>. Accessed on: 9 mar. 2008.

JESUS, P. R. C. A linguagem da dor na propaganda de medicamentos: "a cura pela palavra". Relato de experiência vivida em eventos de Comunicação e Saúde em 2005. UNIrevista, v.1, n.3, p.1-8. 2006. 
JESUS, P. R. C. Propaganda de medicamentos: os éticos e a ética da indústria farmacêutica no Brasil. 2000. Available at: $<$ http://www.eca.usp.br/alaic/chile2000/10\%20GT\%20 2000Com\%20e\%20Salude/Paula\%20Renata.doc $>$. Accessed on: 17 aug. 2007.

KESSLER, D. A.; ROSE, J. L.; TEMPLE, R. J.; SCHAPIRO, R.; GRIFFIN, J. P. Therapeutic-class wars drug promotion in a competitive marketplace. New Eng. J. Med., v. 331, n. 20, p. 1350-1353. 1994.

KOTLER, P. Administração de marketing. 10. ed. São Paulo: Prentice Hall. 2000. 768p.

KRUPKA, L. R.; VENER, A. M. Prescription drug advertising: trends and implications. Soc. Sci. Med., v.20, n.3, p.191197. 1985.

LANKINEN, K. S.; LEVOLA, T.; MARTTINEN, K.; PUUMALAINEN, I.; HELIN-SALMIVAARA, A. Industry guidelines, laws and regulations ignored: quality of drug advertising in medical journals. Pharmacoepidemiol. Drug Saf., v. 13, n. 11, p. 789-795. 2004.

LEXCHIN, J. Interactions between physicians and the pharmaceutical industry: what does the literature say? Can. Med. Assoc. J., v.149, n.10, p.1401-1407. 1993.

MEJIA, R.; AVALOS, A. Printed material distributed by pharmaceutical propaganda agents. Medicina (Buenos Aires), v. 61, n. 3, p. 315-318. 2001.

PIZZOL, F. D.; SILVA, T. da; SCHENKEL, E. P. Análise da adequação das propagandas de medicamentos dirigidas à categoria médica distribuídas no Sul do Brasil. Cad. Saúde Pública, v. 14, n. 1, p. 85-91, 1998.

RESENER, M. C. Análise da qualidade de propagandas de medicamentos fitoterápicos disponibilizadas em Santa Catarina. Florianópolis: UFSC, 2004. 262 p. [Dissertação de Mestrado em Farmácia. Faculdade de Farmácia. Universidade Federal de Santa Catarina].

SILVA, D. R.; BARRETO, M. J.; FACIN, T. C. Publicidade: a fada madrinha da realidade. 2006. In: INTERCOM SUDESTE 2006 - Simpósio de Ciências da Comunicação na Região Sudeste, 11., 2006. Ribeirão Preto, SP. Available at: <http://reposcom.portcom.intercom.org.br/ bitstream/1904/19376/1/Daniela+Silva-Michael+BarretoTereza+Facin.pdf>. Accessed on: 9 mar. 2008.
SMITH, R. Medical journals and pharmaceutical companies: uneasy bedfellows. Br. Med. J., v. 326, n. 7400, p. 12021205. 2003.

SMITH, R. Should medical journals carry drug advertisement? Yes. Br. Med. J., v. 335, n. 7610, p. 74. 2007.

SOBRAVIME. O que é uso racional de medicamentos. Sociedade Brasileira de Vigilância de Medicamentos, Acción Internacional para la Salud - América Latina y El Caribe. São Paulo: Sobravime, 2001. 123 p.

SPIELMANS, G. I.; THIELGES, S. A.; DENT, A. L.; GREENBERG, R. P. The accuracy of psychiatric medication advertisements in medical journals. J. Nerv. Mental Dis., v. 196, n. 4, p. 267-273. 2008.

TEMPORÃO, J. G. A propaganda de medicamentos e o mito da saúde. Rio de Janeiro: Graal. 1986. 183 p.

TREVISOL, D. J.; FERREIRA, M. B. C.; KARNOPP, Z. M. P. A propaganda de medicamentos em escola de medicina do sul do Brasil. Ciência \& Saúde Coletiva. 2007. Available at: $<$ http://www.abrasco.org.br/cienciaesaudecoletiva/artigos/ artigo_int.php?id_artigo=1950>.Accessed on: 6 jun. 2008 .

VILLANUEVA, P.; PEIRÓ, S.; LIBRERO, J.; PEREIRÓ, I. Accuracy of pharmaceutical advertisements in medical journals. Lancet, v.361, n. 9351, p.27-32, 2003.

VLASSOV, V.; MANSFIELD, P.; LEXCHIN, J.; VLASSOVA, A. Do drug advertisements in Russian medical journals provide essential information for safe prescribing? West. J. Med., v. 174, n. 6, p. 391-394. 2001.

ZIPKIN, D. A.; STEINMAN, M. A. Interactions between pharmaceutical representatives and doctors in training. Journal of General Internal Medicine, v. 20, n. 8, p. 777786. 2005. Available at: <http://www.pubmedcentral. nih.gov/articlerender.fcgi?tool=pubmed\&pubmed $\mathrm{id}=16050893>$. Accessed on: 9 mar. 2008.

WORLD HEALTH ORGANIZATION. World Health Assembly. Resolution WHA41.17. Ethical Criteria for Medicinal Drug Promotion. Adopted by the Forty-first World Health Assembly, 13 May 1988. Available at: <http://mednet2. who.int/edmonitor/edition/edm17a.html $>$. Accessed on: 23 jan. 2006.

Received for publication on $01^{\text {st }}$ april 2008 Accepted for publication on $07^{\text {th }}$ november 2008 